\title{
E-BUSINESS SOFTWARE EVALUATION
}

\author{
Victor Fernandez P., Ricardo Chalmeta \\ Grupo Integración y Re-Ingeniería de Sistemas (IRIS) \\ Universitat Jaume I. Castellón. 12071. SPAIN. \\ Tel: 34-964-728343. Fax: 34-964-728435 \\ E-mail: rchalmet@uji.es
}

\begin{abstract}
E-business is a business strategy that is oriented toward the use of the new information and communication technologies, and mainly Internet, as a new way to communicate, to integrate business processes and to improve relationships with customers, suppliers and other enterprise collaborators.

This change towards an e-business strategy is leading to a strong demand by companies for e-business software solutions.

This paper provides guidelines for selecting e-business software according to the intended purpose of software use. The methodology and the basic criteria to be examined in the software evaluation process are listed together with the evaluation of the best commercial e-business software.
\end{abstract}

\section{INTRODUCTION}

An e-business company is an enterprise that integrates the capabilities offered by Information and Communication Technologies (ICT) with Internet in order to carry out their business in an efficient way.

Therefore, the term 'e-business company' arises when firms start to make use of the new possibilities offered by the Internet -in combination with the capabilities already developed in information technologies- to modify or to redesign their business processes so as to make both internal and external communication easier. It must be pointed out that, although conceptually an e-business company does not necessarily have to utilize Internet as a communication channel, the term e-business is intricately linked to the Internet. This is so because the advent of the World Wide Web made it possible to generate new forms of communication that either did not exist before or which could not be implemented due to the prohibitive costs and complexity involved.

This paper is organized as follows. Section 2 gives a brief description of an ebusiness technological infrastructure Section 3 shows the framework in which this research work has been carried out. Section 4 reviews the differences between commercial e-business software applications. In section 5 and 6 , the main results obtained in the evaluation of commercial e-business software are presented, and finally, section 7 outlines main conclusions. 


\section{E-BUSINESS TECHNOLOGICAL INFRASTRUCTURE}

This new model of enterprise incorporates the strategic use of Information and Communications Technologies (which includes, but is not restricted to, the Internet) to build a technological platform that allows interaction with customers, suppliers, employees, projects and partners through multiple communication flows and distribution channels (Damanpour, 2001). Therefore, to achieve the successful implementation of e-business, a suitable technological infrastructure is required in order to automate, improve and, if necessary, define new models of the business processes concerning the management of the relationships the firm have with all their collaborators (Kennerley, 2001), especially in the functional areas that characterize the new models of business processes found in e-business (Yen, 2001): BackSide, SellSide, BuySide \& Supply Chain Management, Internal Relations and External Collaborations \& GroupWare.

\section{EVALUATION OF COMMERCIAL E-BUSINESS SOLUTIONS}

The IRIS group at the Universitat Jaume I of Castellón, Spain, has been working on the project entitled "A methodology for the implementation of an e-business system" since 2003. The objective was to develop and validate a formal methodology that guides the process of developing and implementing an e-business system in a company.

One of the activities carried out as part of this project has been to evaluate the best commercial solutions for the development of a technological infrastructure for e-business. The procedure followed to evaluate these solutions is detailed below.

1. Selection of the best technological solutions for e-business.

2. Identification of the general, technical and functional criteria that a computer solution for e-business has to satisfy.

3. Analysis of the programs selected taking into account the general and technical criteria.

4. Evaluation of each of the computer applications selected based on the functional criteria that were taken into account.

5. Identification of the strong and weak points of each application, as well as a comparative study of the different applications.

Data for the study was collected by means of questionnaires and interviews with members of staff from the manufacturing and implementing companies, from publications and articles containing information about e-business software, online demonstrations provided by the distributors of the software packages that were evaluated, telephone conversations held with suppliers of the computer applications and visits to sites and forums on the Internet that are specialized in e-business.

\section{SELECTION OF COMMERCIAL E-BUSINESS SOLUTIONS}

The differences between commercial e-business software depend on the business 
area they are intended for. Hence, four types of applications can be observed:

1. Software applications that offer specific solutions, such as Enterprise Portals (EIS), E-business Portals (e-Commerce) and e-Shop Managers, Knowledge Managers, Collaborative Applications, customers and/or suppliers analysis, or contacts administration.

2. E-business software applications. These refer to software packages specialized in the management of the business transactions that take place among enterprise, customers and suppliers, and the financial institution used to complete the purchasing and selling processes.

3. Software applications aimed at the customer service module. This group includes software packages specialized in the automation, via the Internet, of the sales and marketing module, and in features such as telesales skills for managing advertising campaigns.

4. E-business software applications that cover all the business areas of a company. These are modular solutions that can be easily adapted to the characteristics of customers and can support large databases and different operating systems. Management of the relationships with customers, suppliers and employees is a highly automated process in the majority of these solutions. Most of the software packages that have been evaluated belong to this category.

The final list of commercial solutions to be evaluated (selected among the mainly ebusiness applications), was as follows:

Table 0 -Commercial e-business solutions to evaluate

\begin{tabular}{|c|c|}
\hline $\begin{array}{ll}\text { - } & \text { IBM WebSphere Portal - } \\
\text { - } & \text { Express Multiplatform, v5.1 } \\
\text { - } & \text { Sun Microsystems ONE Portal } \\
& 6,3.0 \\
\text { - } & \text { BEA WebLogic Portal } 8.1 \\
\text { - } & \text { Siebel eBusiness } 7.7 \\
\text { - } & \text { PeopleSoft Portal Solutions } \\
& \text { (Enterprise \& EnterpriseOne) } \\
\text { - } & \text { Vignette V7 eBusiness Portal }\end{array}$ & $\begin{array}{l}\text { - e-Synergy Suite by Exact } \\
\text { Software } \\
\text { - } \text { Red Hat Portal Apps\&Server } 1.0 \\
\text { - } \text { mySAP eBusiness Suite } \\
\text { - Cesser WebServices - Business } \\
\text { Portal Solution - } \\
\text { ONYX Enterprise e-Business } \\
\text { Portal 5.0 } \\
\text { - MicrosoftSharePoint Portal } 2003 \\
\text { - Livelink 9.2 by OpenText } \\
\text { - Zope Plone 2.0/CPS }\end{array}$ \\
\hline
\end{tabular}

\section{EVALUATION OF COMMERCIAL E-BUSINESS SOLUTIONS}

The criteria taken into account in order to evaluate existing business solutions can be grouped in three large areas:

a) General requirements, which refer to different aspects of the enterprise that develops and distributes the e-business solution: Distribution Company; Location; Web Site; Years of experience; No. of Employees; No. of Customers; No. of Partners and Worldwide Presence; Market 
Objective; Languages available; Training and Maintenance; Cost; Time needed in a company to implement the software.

b) Technical requirements, which analyze the technical characteristics of the solutions: Adaptation to the environment; Relational Management System /Database Manager; Hardware Requirements; Source Code Languages; Server application software; Integration with other systems that are already running; Software architecture; Robustness of the architecture; Software Connectivity; Configuration and Adaptation to the customer; Integration with BackSide (ERP); Security; Safety; Electronic trading contracts; Conformity with e-business frameworks; Customer Relations Management (Integration with CRM, eCRM); Supply Chain Management (Integration with SCM); e-Commerce Applications (Allard, 2001); Collaborative Applications and NetSourcing (Borghoff, 2000); Content Management; Integration with XML and Graphic tools for WorkFlow.

c) Functional requirements, which show the operational characteristics that a technological infrastructure for e-business must satisfy. The functional requirements have been organized into three modules: Analytic/Strategic (see Table 1), e-Business and Knowledge Management (see Table 2) and General Administration/Maintenance (see Table 3).

\subsection{Analytic/Strategic Module Requirements}

This module is responsible for, among other things, the control, integration and online creation of reports based on the data acquired from the operational information systems in the enterprise. The data are turned into information that is useful for running diagnoses of the management of the relationships with customers, suppliers, partners and employees, as well as for assessing their cost-effectiveness (in the case of customers and suppliers), their usability and the improvement in internal efficiency (in the case of in-house company staff), and for automatically defining (by means of alerts for the user involved in each case) opportunities for improvement (Chalmeta, 2005).

Table 1 - Analytic/Strategic Functional Requirements

\begin{tabular}{|c|l|}
\hline $\begin{array}{c}\text { Functional Requirement } \\
\text { Generation of Reports }\end{array}$ & $\begin{array}{l}\text { It allows to analyze the user's behavior and to } \\
\text { create reports. }\end{array}$ \\
\hline $\begin{array}{c}\text { Graphic/Statistical and } \\
\text { Planning/Forecasting } \\
\text { Tools }\end{array}$ & $\begin{array}{l}\text { Provide easy access to graphic tools in order } \\
\text { to conduct statistical analyses of sales/income } \\
\text { as well as planning/forecasting and lending } \\
\text { support to the previous requirements. }\end{array}$ \\
\hline
\end{tabular}

\subsection{E-Business and Knowledge Management Module Requirements}

The purpose of this module is to provide customers, suppliers, business partners, employees etc. the access, by means of the Internet and/or a Web Service, to each of the functional areas that have been identified Backside, SellSide, BuySide \& Supply Chain Management, Internal Relations and External Collaborations \& GroupWare. 
The functional requirements identified for each of the areas into which the e-business module is divided are detailed below:

Table 2 - E-Business and Knowledge Management Functional Requirements

\begin{tabular}{|c|c|}
\hline Functional Requirement & Description \\
\hline \multicolumn{2}{|c|}{ SellSide/BuySide Functional Common Requirements } \\
\hline $\begin{array}{l}\text { Capacity of the Portal and } \\
\text { Individualized } \\
\text { Customer/Supplier Service }\end{array}$ & $\begin{array}{l}\text { Self-configuration updating the personalized } \\
\text { information about the customer/supplier. } \\
\text { Tools allowing private access to specific } \\
\text { functions: records of orders, dispatch notes, } \\
\text { invoices, offers, discounts, etc. }\end{array}$ \\
\hline Facilitates email traffic & $\begin{array}{l}\text { Handles the volume of email input and output. } \\
\text { Enables automatic electronic responses. }\end{array}$ \\
\hline $\begin{array}{l}\text { Administration of } \\
\text { interactivity with } \\
\text { multimedia support }\end{array}$ & $\begin{array}{l}\text { Personalized customer/supplier access to a } \\
\text { chat with a representative from the enterprise } \\
\text { in a } 1: 1 \text { or } 1: \mathrm{N} \text { session. }\end{array}$ \\
\hline $\begin{array}{l}\text { Order processing and } \\
\text { administration of } \\
\text { quotations }\end{array}$ & $\begin{array}{l}\text { Feature allowing automatic processing of } \\
\text { orders, including payment, taxes and transport } \\
\text { management. }\end{array}$ \\
\hline \multicolumn{2}{|c|}{ SellSide Function (Sales Management) } \\
\hline $\begin{array}{l}\text { Administration of Help } \\
\text { Desk }\end{array}$ & $\begin{array}{l}\text { Handles the entry of requests for help from } \\
\text { knowledge bases, FAQ, etc. }\end{array}$ \\
\hline $\begin{array}{l}\text { Administration of } \\
\text { Estimates and Orders \& } \\
\text { Life Cycle Tracking }\end{array}$ & $\begin{array}{l}\text { Management and tracking feature including } \\
\text { customer's ref., date, automation of estimate- } \\
\text { order step, as well as the possibility of looking } \\
\text { up status, validity, details, etc. }\end{array}$ \\
\hline After-Sales Service & To solve customer problems by Internet. \\
\hline \multicolumn{2}{|c|}{ BuySide Function (Purchase/Supply Chain Management - SCM) } \\
\hline $\begin{array}{l}\text { Catalogs and Delivery } \\
\text { Dates Management }\end{array}$ & $\begin{array}{l}\text { Management of supplier's products, catalogs, } \\
\text { codes, prices, delivery dates, etc. }\end{array}$ \\
\hline Auctions & $\begin{array}{l}\text { Management of offers for an order made } \\
\text { through the business portal. }\end{array}$ \\
\hline Purchases Administration & $\begin{array}{l}\text { To follow the workflow established for an } \\
\text { order to be approved by the different people. }\end{array}$ \\
\hline $\begin{array}{l}\text { Management of dispatch } \\
\text { notes and Self-Invoicing. } \\
\text { Processing }\end{array}$ & $\begin{array}{l}\text { E-business Re-Engineering of the processes } \\
\text { involved in managing dispatch notes/invoices, } \\
\text { approval, claims, digital signing and sending } \\
\text { by EDI/XML for the dispatch note-invoice- } \\
\text { payment stage, thus eliminating shortcomings } \\
\text { found in SCM. }\end{array}$ \\
\hline \multicolumn{2}{|c|}{$\begin{array}{l}\text { InSide/OutSide (Relations and Collaborations - CSCW) and Knowledge } \\
\text { Management in the e-Business Company }\end{array}$} \\
\hline Document Manage & $\begin{array}{l}\text { Workflow document management as signing } \\
\text { approval, revision, dispatching and/or } \\
\text { corporative rejection. }\end{array}$ \\
\hline
\end{tabular}




\begin{tabular}{|c|l|}
\hline Automated Workflow & $\begin{array}{l}\text { Automation of business processes in a } \\
\text { structured and collaborative environment, } \\
\text { which ensures a predefined running order } \\
\text { (Khoshafian, 1995). }\end{array}$ \\
\hline Placeholder & $\begin{array}{l}\text { Possibility of automatically sending } \\
\text { personalized emails. }\end{array}$ \\
\hline Alerts Management & $\begin{array}{l}\text { Management of Alerts and Alarms for } \\
\text { predefined events via the e-business solution. }\end{array}$ \\
\hline $\begin{array}{c}\text { Electronic Mail, Electronic } \\
\text { Agenda and Conference }\end{array}$ & $\begin{array}{l}\text { Management of personalized and integrated } \\
\text { e-business accounts for customers/ suppliers/ } \\
\text { employees, as well as a private } \\
\text { agenda/conference feature. }\end{array}$ \\
\hline $\begin{array}{c}\text { Decision Making Systems } \\
\text { and Electronic Board } \\
\text { Rooms }\end{array}$ & $\begin{array}{l}\text { The aim here is to improve productivity in } \\
\text { decision-making, whether it is achieved by } \\
\text { speeding up the decision process or by } \\
\text { increasing the quality of the decisions } \\
\text { stemming from a virtual meeting. }\end{array}$ \\
\hline $\begin{array}{c}\text { Intranet/Extranet } \\
\text { Oecuring (certificates, authentication and non- } \\
\text { repudiation service, among others) e-business } \\
\text { accesses to the enterprise and associated } \\
\text { measures to achieve integration of processes. }\end{array}$ \\
\hline Control/Tracking of & $\begin{array}{l}\text { Generation of Features allowing Outsourcing } \\
\text { Management. }\end{array}$ \\
\hline
\end{tabular}

\subsection{General Administration/ Maintenance Requirements}

In addition to the functional requirements above, the system must also include other capabilities such as:

Table 3 - General Management/Maintenance Functional Requirements

\begin{tabular}{|c|l|}
\hline Functional Requirement & \multicolumn{1}{|c|}{ Description } \\
\hline Main Administration & $\begin{array}{l}\text { Content Management, Integration with } \\
\text { WorkFlow/CSCW and General Configuration, } \\
\text { thus allowing administration of the contents of } \\
\text { the jobs and alerts module, among other } \\
\text { associated features. }\end{array}$ \\
\hline Administration of Users & $\begin{array}{l}\text { Integrated Management of Roles, Profiles, } \\
\text { according to corporative requirements, } \\
\text { integrated with features for generation of the } \\
\text { Map of the Organization. Associated Security } \\
\text { Management. Records Management. }\end{array}$ \\
\hline $\begin{array}{c}\text { Management/Analysis of } \\
\text { Customers, Suppliers, } \\
\text { Business Partners and } \\
\text { Employees }\end{array}$ & $\begin{array}{l}\text { Segmentation, Profiles and Customer } \\
\text { Potential, integrated via webService. } \\
\text { Integrated Analysis of the lifetime and } \\
\text { economic value of customers, suppliers and } \\
\text { business partners of the enterprise. }\end{array}$ \\
\hline
\end{tabular}




\section{COMPARATIVE STUDY}

From the list of requirements taken into account for each of the computer applications under evaluation, the following should be highlighted:

a) Among the general requirements, one special point of interest is whether there is a firmly established distributor in the country or not, its experience in a particular sector or whether suitable maintenance and training are provided once the application has been implemented.

b) With respect to the technical requirements, the solutions studied here present very similar characteristics. In general terms, they have an open architecture of $\mathrm{n}$ layers that ensures it will be possible to expand the system in the long term and to use well-known servers such as Oracle, MSSQL Server, and so on. The main languages used in the development of the solutions include Java, JavaScript, HTML and XML, among others such as Phyton, DTML, PHP or ASP. Moreover, they can be closely integrated with ERPs, e-commerce applications, collaborative and teamwork tools, CRM software (especially e-CRM) and powerful content managers (CSM); furthermore, most of them run under the MS Windows 95/98/2000/NT and Windows XP operating systems and to a lesser extent on UNIX/Linux. On the other hand, the majority can be integrated with the different ERP and CRM that exist on the market, depending on each application, and most of them develop graphic workflow tools and integration with XML.

c) Lastly, with respect to functional requirements, the Fig.1 shows the score assigned after the analysis carried out on each commercial solution. Each of the subsections used to classify the functional requirements was given a value between 0 and 3, where: 0 - not available, 1- acceptable, 2-good, 3- excellent.

\begin{tabular}{|c|c|c|c|c|c|c|}
\hline \multirow[b]{2}{*}{$\begin{array}{l}\text { Commercial sw } \\
\text { solutions }\end{array}$} & \multirow{2}{*}{$\begin{array}{l}\text { Analyticl } \\
\text { Strategic }\end{array}$} & \multicolumn{4}{|c|}{ E-Business and Knowledge Management } & \multirow{2}{*}{$\begin{array}{l}\text { Administration } \\
\text { Maintenance }\end{array}$} \\
\hline & & Sellside & Buyside & $\begin{array}{c}\text { Inside/Out } \\
\text { Side }\end{array}$ & $\begin{array}{l}\text { Knowledge } \\
\text { Management }\end{array}$ & \\
\hline $\begin{array}{c}\text { IBM WebSphere Portal - Express } \\
\text { Multiplatform, v5.1 }\end{array}$ & 1 & 3 & 3 & 3 & 3 & 2 \\
\hline Oracle e-Business Suite $11 \mathrm{i} .10$ & 1 & 2 & 3 & 3 & 1 & 1 \\
\hline Sun Microsystems ONE Portal 6,3.0 & 1 & 3 & 1 & 3 & 2 & 3 \\
\hline BEA WebLogic Portal 8.1 & 1 & 3 & 1 & 3 & 1 & 3 \\
\hline Siebel eBusiness 7.7 & 2 & 3 & 0 & 0 & 3 & 3 \\
\hline $\begin{array}{l}\text { PeopleSoft Portal Solutions } \\
\text { (Enterprise \& EnterpriseOne) }\end{array}$ & 3 & 2,5 & 2,5 & 3 & 2 & 2 \\
\hline e-Synergy Sulte de Exact Software & 1 & 3 & 3 & 2 & 3 & 2 \\
\hline Vignette V7 eBusiness Portal & 1 & 1 & 0 & 3 & 3 & 2 \\
\hline Red Hat Portal Apps \& Server 1.0 & 2 & 0 & 0 & 3 & 2 & 3 \\
\hline mySAP eBusiness Suite & 0,5 & 3 & 3 & 3 & 2 & 2 \\
\hline $\begin{array}{c}\text { Cesser WebServices - Solución } \\
\text { Portal de Negocio- }\end{array}$ & 1 & 2 & 2 & 1 & 0 & 3 \\
\hline $\begin{array}{c}\text { ONYX Enterprise } \theta \text {-Business Portal } \\
5.0\end{array}$ & 0 & 3 & 1 & 2 & 2 & 2 \\
\hline Microsoft SharePoint Portal 2003 & 1 & 0,5 & 0,5 & 2 & 1.5 & 1 \\
\hline Livelink 9.2 de OpenText & 1 & 3 & 2 & 2 & 2 & 2 \\
\hline Zope Plone 2.0/CPS & 0 & 1 & 0,5 & 2 & 3 & 2 \\
\hline
\end{tabular}

Figure 1 - Comparative Study of the functional requirements 


\section{CONCLUSION}

The ICT and the Internet have meant that companies are changing the way they do business, so that today e-business is no longer an alternative but rather an imperative fact that each company, every organization must pursue and accomplish.

To implement an e-business system, it is necessary to develop a supporting computer infrastructure to automate and improve the business processes linked with managing the company's relationships with employees, customers, suppliers, creditors, and other collaborating partners.

In this article we have outlined the methodology followed to evaluate the commercial e-business solutions with the greatest presence on the market. As a result of the study conducted, it can be concluded that in general they all provide good management in the area of integration with corporative ERP and CRM. Nevertheless, the supplier relations (SRM) and value chain management (SCM) modules, as well as knowledge management and the analytic module, need to be more powerful as far as the generation of reports, planning and controlling goes.

\section{Acknowledgments}

This project has being funded by CICYT DPI2003-02515, FUE-UJI and different enterprises.

\section{REFERENCES}

1. Allard, S., W Holsapple, C. "Knowledge Management as a key for e-business competitiveness: From the Knowledge chain to KM audits". The Journal of Computer Information Systems, Stillwater, US, 2002; 42: 19-26

2. Borghoff, U., Schlichter, J. "Computer-Supported Cooperative Work: Introduction to Distributed Applications". Springer, 2000.

3. Chalmeta, R., Grangel, R. "Performance Measurement Systems for Virtual Enterprise Integration". Computer Integrated Manufacturing. 2005; 73-84

4. Damanpour F. "E-business e-commerce evolution: Perspective and strategy", Managerial Finance, Patrington $2001 ; 27: 16-18$

5. Kennerley M., Neely A. "Enterprise resource planning: Analysing the impact. Integrated Manufacturing Systems", 2001; 12:103-113,

6. Khoshafian, S., Buckiewicz, M. "Introduction to Groupware, Workflow, and Workgroup computing". Ed. John Wiley \& Sons, Inc, 1995

7. Yen David C., Chou David C., Chang Jane. "A synergic analysis for web-based enterprise resources planning systems". Computer Standards \& Interfaces, 2002; 24: 337-346 